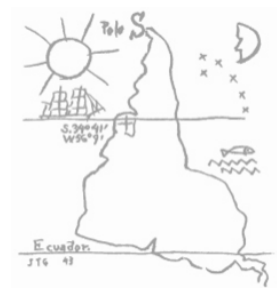

ALTERNAUTAS

Katucha Bento, Andrea Sempértegui, Heriberto Ruiz Ponce and Louis di Paolo

\title{
Dialogues of Indigenous Afro-Latinxs (re)existence: Possible decolonialities
}

Alternautas is a peer reviewed academic journal that publishes content related to Latin American Critical Development Thinking.

It intends to serve as a platform for testing, circulating, and debating new ideas and reflections on these topics, expanding beyond the geographical, cultural and linguistic boundaries of Latin America - Abya Yala. We hope to contribute to connecting ideas, and to provide a space for intellectual exchange and discussion for a nascent academic community of scholars, devoted to counter-balancing mainstream understandings of development.

How to cite:

Bento, K. Sempértegui, A. Ruiz Ponce, H. and di Paolo, L. (2019), Dialogues of Indigenous Afro-Latinxs (re)existence: Possible decolonialities, Alternautas, 6(1), 33-55. URL :

http://www.alternautas.net/blog/2019/4/9/dialogues-of-indigenous-afrolatinxs-reexistence-possible-decolonialities

Editor : Alternautas

http://www.alternautas.net

London, UK.

ISSN - 2057-4924 


\section{Dialogues of Indigenous Afro-Latinxs (re)existence: Possible decolonialities ${ }^{2}$}

\section{Introduction}

This article, in its dialogue format, is the result of a meeting among academics who delivered papers in the symposium "Decolonising the Global North: Afro-Latin America, the Caribbean and Abya Yala in diaspora”. It took place at the 56th

' KATUCHA BENTO is a Teaching Fellow at the University of Leeds and visiting researcher at Leeds Beckett University, UK. She is an associate member of the Research Network in Queer Studies, Decolonial Feminisms, and Cultural Transformations, Universidad Justus-Liebig, Germany.

ANDREA SEMPÉRTEGUI is PhD Researcher at the International Graduate Centre for the Study of Culture (GCSC), at the Justus-Liebig University Giessen, and member of the QDFCT (Research Network in Queer Studies, Decolonial Feminisms, and Cultural Transformations, Justus-Liebig University, Gießen, Alemania).

HERIBERTO RUIZ PONCE is Reader/Professor at the Instituto de Investigaciones Sociológicas (IISUABJO, Mexico).

LOUIS DI PAOLO is a PhD Researcher in the Department of Spanish and Latin American Studies at the Macquarie University, Australia. E-mail: louis.di-paolo@mq.edu.au

This article was originally published in http://www.alternautas.net/blog/2019/4/9/dialogues-ofindigenous-afro-latinxs-reexistence-possible-decolonialities, on April 9th, 2019.

${ }^{2}$ We are deliberately using the letter " $x$ " and the term "Latinxs" without the use of "o/a" or "@", as a political decision of disidentification with the constructions of gender binaries that make restrictive references to multiple possibilities around the fluidity and performativity of identification of gender/sex/sexuality. This positionality makes reference to contributions in Queer and/or Latinx literature such as Elondust Patrick Johnson, Gloria Anzaldúa, Juliana Huxtable, Omise'eke Natasha Tinsley, Roderick Ferguson, Sara Ahmed, Simone Browne, among others who are inspiring to the process of challenging debates on gender/sex/sexuality and its intersections.

** 
International Congress of Americanists (ICA), on the 20th July 2018. ${ }^{3}$ This collective work summarises the presented papers and displays them, critically, in the form of a dialogue, providing at the same time the impressions and perceptions of each one of the participants of the symposium about said papers. It is an exchange of knowledge about topics that, although initially seeming to be diverse, are connected in a dialogical way to reflect on the colonial heritage and the oppression experienced by Indigenous and Afro-Latinx groups.

This set of oppressions to which we refer also have touched our bodies and our feelings, as each of the authors self-identifies as non-white with a Latinx American identity, some of us with lower class origins, and half of us with queer identities. This article seeks to centralise the experiences of the participants of our research front, with the aim of portraying realities that are systematically marginalised by the coloniality of power (Quijano, 2000). In this way, our purpose is to identify possibilities to decolonise practices and discourses that oppress our siblings in Abya Yala.

We warn readers that this is not a traditional academic article, although our ideas also stem from dialogues with decolonial thinkers, Black feminists, indigenous and antiracist activists. We believe that this shared authorship is not only a manifest of style but an empowering tool of epistemic disobedience, which demands our space of reexistence through our collective work. The structure of the text below will follow the order of the papers as they took place during the symposium. Starting with the voice of Katucha Bento, we present a Black feminist methodological framework that approaches the experiences of Black women who survive the oppressions of whiteness. Andrea Sempértegui comments on this presentation, placing emphasis on the issues that Katucha draws our attention to. One example of this is the validation of "sentirpensar" (feel-think) by Black women inspired by Audre Lorde's notion of

\footnotetext{
${ }^{3}$ For more information regarding this Symposium 8/11 "Descolonizando el Norte Global: AfroLatinoamérica, el Caribe y Abya Yala en diáspora" and its participants, access the full 56th ICA programme on page 273: http://ica2018.es/mysite/wp-content/uploads/2018/o7/PROGRAMAFINAL.pdf.
} 
the "erotic". Another example is the creation of an "Amefricaladina" place location of resistance, proposed by the Brazilian Black feminist author Lélia Gonzalez.

The dialogue between Andrea and Katucha continues with Andrea's analysis of practices of resistance and re-existence. Specifically, Andrea focuses on the territorial struggle of indigenous women against the expansion of extractive projects in the Ecuadorian Amazon. Heriberto Ruiz Ponce comments on this presentation with a careful analysis of how neo-extractive projects are part of a project of modernity that reveals the way that the coloniality of power (Quijano, 2000) is historically manifested in Abya Yala.

The analysis presented by Heriberto on the struggles for the validation of Afro and Black identities is understood from his exposition on the coloniality of power (Quijano, 2000) in the Mexican context. This contribution is inspired by the creation of the Consejo Afromexicano (Afromexican Council) in the Villa de Tututepec de Melchor Ocampo, Oaxaca, presenting us with an organisational practice of resistance against the invisibility reproduced by the Mexican State. It is important to highlight that this research was done in conjunction with the researcher Selma Jazmín Vázquez from the Facultad Latinoamericana de Ciencias Sociales (FLASCO). The comments on this presentation are from Louis Di Paolo - our special guest at the symposium who focuses on the oppressive role of the Mexican State as an instrument of domination, which at the same time has created possibilities for new racial identification processes of African descent stemming from the constitutional reform.

The fourth topic is summarised by Louis, who presents his critical reflections on LGBTQ+ tourism in Uruguay. The author questions the legitimacy of the alternative spaces for LGBTQ+ groups, which although marginalised within patriarchal society, create and reproduce other types of invisibility within themselves. Katucha's comments on this paper are from a Black feminist reading and Critical Race Studies on Queer spaces. Katucha poses questions about who they are and what the place is of validation and 'queer' identification. The commentator then concludes with a provocation on the need to rethink intersectionality as a fundamental tool of our decolonial studies. 
This dialogue finishes by briefly mentioning some points of convergence between the themes presented in the papers that can promote decolonial practices. With this, the intention is not to provide a conclusion but to encourage the continuation of debate and dialogue about projects of re-existence that can strengthen peoples who have been marginalised and racialised, such as non-whites, by the coloniality of power (Qujano, 2000).

\section{Creating an AMEFRICALADINA standpoint: AfroBrazilians Healing and Surviving Whiteness in the European Setting}

KATUCHA BENTO: My work is concerned with the broad topic of intersectional oppressions (Crenshaw et al., 1996) in the experiences of Black Brazilian women in diaspora, negotiating politics of identification in their everyday lives in the United Kingdom (UK). I understand such oppressions to be intrinsically related to the coloniality of power (Quijano, 2000), which imposes racial roles and stereotypes that, for this discussion, are interwoven with gender, nationality and (dis)ability. My interest is in presenting how Black Brazilian Women are negotiating racial and national identities in the UK, where there are different ways to identify as the "Other" (Hall, 1996), non-white/non-European/non-English speaking. This context of a "coloniality of power" affects social interactions, migration experiences and, above all, the ways of surviving intersectional oppressions. Therefore, the processes of "Othering" (Hall, 1996) are negotiated in the affective economy (Ahmed, 2004a, 2004b; Muñoz, 2006; Gutiérrez Rodríguez, 2010; Tate, 2015). Here, I am making reference to the relationship between coloniality of power and how it affects notions of Blackness, woven through the dialogue that is forming the tapestry of diasporic experiences of Black Brazilian women who live in the UK. Affect circulates, involving orientations towards others (Ahmed, 2004a, p. 4). This makes the identifications relational, negotiated to the point of considering the potential translations of relationality within a larger social sphere (Muñoz, 1999, p. 677). Within the migratory trajectory, notions, perceptions, and translations of Brazilian Blackness are present, which are negotiated in the British setting, where the intersectionality of race, gender and nationality suggest a new dynamic of oppression, struggle and 
agency. Intersectionality is a relational interaction that "makes visible the multiple positioning that constitutes everyday life and the power relations that are central to it" (Phoenix and Pattynama, 2006, p. 187).

To talk about this affect economy that is present in the lives of Black Brazilian women in the UK, I use the concepts of "Amefricaladina" by Lélia Gonzalez (1988) and "the use of the erotic" by Audre Lorde (1984). These concepts work as methodological tools of re-existence that allow me to navigate complex realities and envision strategies of how to negotiate Blackness, gender and nationality. They are methodological tools for re-existence because, on the one hand, Amefricaladina means weaving together Black and Indigenous groups (racialised categories) with geographic and national origins (Caribbean, Latin American and African), claiming a decolonial positionality of constant "negation" (negação) of the place that racism reserves for people racialised as non-white (Gonzalez and Hasenbalg, 1982; Gonzalez, 1988). On the other hand, the use of the erotic is what functions to validate and understand Black women's experiences by reclaiming our/their space of articulation and its power of liberation from oppressive chains. Therefore, the erotic is present as the ability to connect to share experiences and differences, creating an Ameficaladina space. From this space, we - Black women - re-exist the oppressions through our own situated standpoint (Collins, 1990).

With this premise of validating the knowledge of the Black Brazilian women living in the UK, I recount Ceci's Herstory. ${ }^{4}$ It is about a Black Brazilian woman who arrived in Brazil after a few frustrating attempts at developing her professional career in Brazil. She faced a few perils, risks and difficulties in finding a job and learning how to speak English. She then met her husband, but later asked for a divorce due to constant domestic violence and lack of action by police when Ceci sought

\footnotetext{
${ }^{4}$ Herstory is a concept used by Black feminists, remarkably well expressed by Hazel V. Carby (1982) in her paper "White Woman Listen!: Black Feminism and the Boundaries of Sisterhood". Herstories is a way to denounce the preconceived and universalising ideas perpetuated by white hegemonic feminism, validating the intersections of identities, oppressions and needs of Black women. Herstory is a political way of validating the enunciation utterance of knowledge, pain and liberation of women racialised as non-white through their systematically invisible Herstories.
} 
institutional support. During this relationship, there was an episode of violence when the police were called, but the officers dismissed her claims and did not record the event as domestic abuse. The judge responsible for the divorce process did not recognise her call to the police, nor the proof presented to demonstrate the abuse she suffered at the hands of her husband as valid evidence.

Because of this, her migratory status in England was at risk of being made illegal (without a justification for filing divorce, she would not be able to continue her application for a resident permit through marriage). Due to a car accident, Ceci acquired a physical disability, which aggravated her emotional, psychological, financial and legal situation in the country. Ceci defined this moment in Herstory as when she understood what sadness meant. However, this moment was also when she 'made use of her erotic', finding the strength to seek resources and help to understand her new condition as a person with disability, creating a support community and starting to look for work.

Far from romanticising the stories of Black women overcoming their exclusion or suggesting from a meritocratic perspective that the experience of Ceci is the fruit of an individualised struggle, this Herstory shows the possibility of creating an Amefricaladina standpoint. This is the opportunity of weaving together groups of resistance to achieve two things. Firstly, it stands up to the socially normalised aggression of whiteness and its mortal consequences. Secondly, because the Black feminist standpoint in Ceci's experience teaches us the use of the erotic (Lorde, 1984) - the potential of self-love - is real and revolutionises the practices of re-existance and liberation.

Today, Ceci has learned how to live with depression, with the emotional lows, and knows her vulnerabilities. She has also found love with another partner and works in an area that allows her to adapt to her reality as a person with disability and visit her mother from time to time, in Brazil. In my reading, Ceci's use of the erotic (Lorde, 1984) is evident in the way she has found the space to be herself within the British 'hostile environment' (Arif and Wangari-Jones, 2018). In conclusion, my contribution does not seek to place Black women in spaces of victimisation, but to 
recognise that, despite intersectional oppression, there is the possibility of creating actions in which our Herstories also (re)exist and are woven together. This weaving is a proof of our existence, systematically invisible to the eyes of the coloniality of power framed by/through whiteness, of our re-existence to overcome whiteness, and of our Amefricaladina (Gonzalez, 1988) possibilities of erotically (Lorde, 1984) flourishing beyond whiteness.

Now I invite Andrea, a fellow symposium participant, with whom I coexisted during my experience as Research Fellow in the International Graduate Centre for the Study of Culture (GCSC), at the Justus-Liebig Gießen, Germany. Andrea, what are your reflections and interpretations of my presentation?

ANDREA SEMPERTEGUI: Before starting with my reflection on your paper, I think it is important to note the standpoint you are talking from. Then, I will continue by mentioning what caught my attention during your presentation.

Katucha Bento is an Afro-Brazilian activist, samba dancer, teaching fellow and $\mathrm{PhD}$ researcher in Sociology at the University of Leeds, UK. Katucha, who is also the organiser of this symposium, shared with us a fragment of her research and reflections, which connect migration, racism, gender and affect from a decolonial and Black feminist perspective.

First, she introduced us to the imaginary of Leila Gonzalez, an Afro-Brazilian thinker, anthropologist and politician, through the term of "Amefricaladino". While this word is an example of how Leila Gonzalez creates a language that weaves together Black and indigenous resistance against racism, the term also produces places of enunciation and re-existence to continue the struggle and legacy of people like the "Amefricaladina" Marielle Franco. This activist and politician was assassinated in March 2018 in the context of her activism and political work against police violence in the favelas in the municipality of Rio de Janeiro.

Thus, starting with the statement that "Marielle is present", Bento presented the political and everyday dimensions of her doctoral research. This research project 
focuses on how Afro-Brazilian migrant women create "Amefricaladina" places to reexist racism and the normative impositions of whiteness in the UK. Using the notion of the "erotic" from the African-American poet and feminist Audre Lorde, which refers to a process of feeling "oneself" and of recreating places from which we can speak and be, Bento introduced us to the herstory of "Ceci".

Learning about Ceci's life through the voice of Bento was a crucial experience to "feel-think" about how the process of the "erotic" goes beyond creating a rationalised and reflected-upon place for resistance. Ceci's herstory also revealed to us the possibilities of finding spaces for empowerment that arise from life experiences marked by denial and suffering in the diaspora. The process of feeling through these experiences creates spaces for self-love and communal solidarity even though they seem impossible in a world marked by racism and patriarchy.

Departing from the need to connect and create solidarity and re-existence, I continue this dialogue by introducing my presentation, which weaves together extractivism and indigenous women's resistance in the Amazon from a decolonial perspective.

\section{Kawsak Sacha: Re-existence beyond Resistance}

ANDREA SEMPERTEGUI: This paper is connected to the symposium's theme by reversing its objective. Named "Decolonizing the Global North", the symposium sought to trace the influence of Afro-Latin American, Afro-Caribbean and indigenous populations in socio-cultural and political formations in the Global North. My presentation, however, showed how the territorial struggles currently taking place in Abya Yala are connected to the historical-structural forms that have determined which populations and territories should be sacrificed in the name of hegemonic and capitalist ways of living in the Global North. Inspired by Cedric Robinson's thinking, I focused on how the expansion of extractive projects in the Ecuadorian Amazon is part of what he called "racial capitalism" (Robinson 1983). This term illuminates how previous phases of racialised expropriation continue to have repercussions today and have even intensified by deploying new techniques of racialised and gendered exclusion and occupation (Bhattacharyya 2018). This 
historical contextualization was critical to reflect on what forms of power permeate the territorial struggles taking place in Ecuador, without reducing them to mere resistance movements against the capitalist occupation.

I began my presentation by connecting and differentiating myself from academic debates on "neo-extractivism". This debate was born from a dialogue between various academics (Alberto Acosta 2012, Eduardo Gudynas 2010, Maristella Svampa 2011, among others), who have reflected on the question of why progressive governments in Latin America have continued and even intensified extractive projects. In the case of Ecuador, despite the government of Alianza Pais having promoted an environmental agenda since 2006, oil and mining extraction have expanded throughout the country and were even justified by governmental discourse as a necessary measure to eradicate poverty. While I agree with many of the reflections generated in the context of this debate, especially in relation to how the neo-extractive developmental model facilitated new strategies of territorial occupation, my presentation sought to reveal the profoundly colonial, racist and patriarchal roots underlining current processes of territorial occupation for the production of raw materials for the Global North.

I mentioned three current examples that reveal which territories, bodies and ways of life are to be sacrificed for the expansion of the 11th Petroleum Oil Round and megamining projects in Ecuador. First, the colonial construction and subordination of the Ecuadorian Amazon as a "periphery" has been crucial for its place in the governmental discourse that seeks to "refound" and "emancipate" the region from poverty with the program "Nueva Amazonía" [New Amazon] (Vallejo and GarcíaTorres 2017). This program consists in expanding the extractive frontiers through social investment projects in indigenous, peasant and protected areas, such as the Yasuní National Park (Vallejo and García-Torres 2017).

A second example of "sacrifice" in the name of extractive development is how the bodies most affected by extractive projects have been racialised, in this case the indigenous bodies, such as the Shuar people. While the Shuar people have historically opposed territorial colonialization and currently resist mega-mining projects in their 
territory, several of their leaders (Bosco Wisum, Freddy Taish and José Tendetza) have been assassinated. These murders are part of the current strategy of persecution and assassination of social leaders who resist extractive activities throughout Abya Yala.

A third example of sacrifice is to be found in development projects such as the "Millennium Cities" in the Ecuadoran Amazon, which sought to eliminate ways of life outside capitalist production relations, as they are considered to be "poverty generators". In the case of Amazonian indigenous women, they have been forced to sacrifice their affective relationships with the forest and their role as self-sustaining suppliers for their families if they want to move to these cities (Cielo et al. 2016).

Nevertheless, indigenous women are not passive victims of extractive occupation. My presentation concluded by showing how the organisation of Amazonian women in the southeastern Amazon is an example of "re-existence" to the extractive occupation. These women organised the "March for Life" in October 2013, with the aim of handing over the Kawsak Sacha (Living Forest) proposal to former president Rafael Correa. The main objective of this proposal was to declare the Amazon as a "living forest" and shows how this group of Amazonian women do more than resist the extractive policies promoted by the government. Instead, they are trying to make visible other forms of relationship and coexistence in Amazonian territories that have historically been denied and go beyond modernist and conservationist imaginaries about the rainforest.

Now I would like to pass the dialogue to Heriberto Ruiz Ponce, who will comment from his perspective about some key aspects of my paper that should be discussed and expressed in our dialogue.

HERIBERTO RUIZ PONCE: My comments regarding your presentation create a walk-through of the colonial history of occupation and territorial exploitation.

Andrea Sempertegui's presentation showed us with very concrete examples how the imaginary of modernity has built horizons and territories without people; they are 
always presented as empty spaces at the convenience of capital, in so far as it justifies the spatial occupation for its exploitation.

The general course of the presented analysis gave an account of the historical process (from the time of the European colonial invasion to the new transnational neoextractivist projects) in which the region that is known today as the Ecuadorian Amazon has been the object of this construction of usable emptiness. However, it is clear that in the review of various geographies and histories located in Abya Yala, the process can be verified as a systematic form of plunder, with its own "continuities as well as colonial and neoliberal ruptures in the strategies of the occupation of lives and territories". In the face of this, the affected villages have sustained diverse forms of resistance, both visible and invisible, against the constant attempts to render them invisible and deny them the option to take control of their lives, territories and sacred places.

In the case at hand, the logic of territorial occupation and the lives affected by extractive projects in the Ecuadorian Amazon arises cyclically, with a similar appearance and discourse, in which, for the execution of public policies, it is necessary to make certain sacrifices in exchange for the general benefit. Characteristic of this balance, it is the indigenous and peasant women that live in proximity to extractivist projects who tacitly receive the classification of "expendable" in the name of progress. According to the presentation, in the centre of the old kingdom of Spain, the Achuar, Shuar, Zapara, Kichwa, Shiwiar, Andoa and Waorani peoples took shape and made their presence known accordingly. Moreover, those of us who listened to Sempertegui's explanation know what the Kawsak Sacha (living forest) is-a movement of creative articulation, driven by women, that occurred in response to the new attacks from the Ecuadorian state to exploit the Amazon.

For an external observer, such as the one writing this commentary, the tensions between the various national and development projects given to the interior of the same country are notorious. Considering the specific case of Ecuador presented to us in the panel and the geographical distances between our countries, it is obviously possible to verify that neither the geographical distance between our countries nor 
their genealogical histories are so different or alien, particularly when it comes time to understand the operation of the coloniality of power (Quijano, 2000), of knowledge, and of existing within our diverse worlds of life.

It is within this field of analysis that I continue in the next dialogue section, presenting the research I carried out with Selma Jazmín Vásquez Bracamontes. In this presentation, I talk about how the coloniality of power operates within the context of Mexico, with emphasis on Afro-Mexican resistance-group fighting for the autonomy of racial self-classification, validating African and Black identities throughout the country.

\section{The Afro-Mexican Council: Crossroads of Identities and Political Opportunities}

HERIBERTO RUIZ PONCE: The "Afro-Descendant Movement" in Mexico has a relatively new outlook that has not yet been sufficiently explored in terms of the construction of political identities. Its specific presence in Oaxaca is generally known in terms of historical information and is preserved in popular culture and collective memory; however, there are not enough updated studies that identify the political dynamics that have recently arisen concerning the State and other cultural groups that struggle to position their agendas on the public stage.

The case of the state of Oaxaca opened a repertoire of legal options that has stimulated the emergence of movements of people of African descent from the configuration of a structure of political opportunity. Here, we specifically refer to the reform of articles 16 and 25 of the Political Constitution of the Free and Sovereign State of Oaxaca in 2013, in which the category of Afro-Mexicans was introduced. This change to the rules of the political game does not mean that previously there were no such organisations and people - for example, Mexico Negro A.C., Africa A.C. and Purpura A.C. - committed for years to promoting the recognition of rights of AfroMexicans. On the contrary, it was precisely the accumulation of their actions and the pressures exercised toward the central powers of the state government, at least during the decade leading up to the change, from which the aforementioned constitutional 
reform was derived. That being said, this reform has given a broader opening to new dimensions in the local political environment, which encourage the collective action of other subjects and groups toward advancing the progression of rights and public policies focused on people of African descent.

Recent experience shows how Afro-descendant communities have sought, through various means, the recognition of their struggles by other international political bodies. Solidarity networks, for example, are one of the main tools that social movements in general have used in recent years, taking advantage of advances in communication technologies. The Afro-movements and their contemporary discourse, in this sense, are having an impact in various areas thanks to these new political environments, their communication potential, and their progress in being recognised as subjects of law. The invisibility of subaltern peoples gradually fades away, and some sectors are adjusting to these new structuring dimensions.

The game and struggle for the constitutional recognition of social actors is often unnecessary, but enough to provide sufficient conditions to generate political opportunities. In the case of the movements of Afro-descendants in Oaxaca, the normative change has been crucial for the activation of organisational processes around the construction of identity. Here the focus is on the Consejo Afromexicano (Afromexican Council), constituted in 2014 in the Villa de Tututepec de Melchor Ocampo (Oaxaca). It is one of the active organisations that, at different levels, has promoted a path of identity construction that deserves to be recognised and the dimensions of its pioneering activities noted. Within its agenda of activities is a coexistence called "Get-together, Talent and Culture," which aims to illuminate Afro-Mexican culture and identify with it. Like the monthly meeting, this activity is carried out alternately and varies in some of the communities that make up the Council, mainly in those whose presence and activities have been scarce.

In our opinion, the ever-greater increase in participation of organised groups in the region that pose a programmatic public agenda on rights and public policies focused on people of African descent responds to a concrete structure of political opportunity. Fundamental to the process we are observing is the reform of the Political Constitution 
of the Free and Sovereign State of Oaxaca, in its articles 16 and 25, where the AfroMexican juridical subject is introduced for the first time. It is a formal, congruent dimension of the political context of the entity, and although it does not necessarily produce a direct transformation in the daily life of Black populations, it does open political opportunities to advance in routes of advocacy with specific objectives.

The constitutional reform has not been the origin of the Afro-movement in Oaxaca. On the contrary, the reform is the result of the accumulation of actions of people and groups that have pushed toward its establishment. In turn, this change in the definition of the rules of the game opens up possibilities for new challenges, both for the State and for the Afro-descendant organisations themselves. For its members, the formation and development of the Council have given them the opportunity to participate in the political sphere, thus contributing to the struggle for the recognition of their rights, and beyond this, motivating them to be included in the movement that has marked the beginning of their self-identification as Afro-Mexicans.

The current collective challenge of the Afro-Mexican Council involves the investment of much energy into different dimensions and at different times. Their survival or decline in the national socio-political arena will depend on the adjustment of their common objectives, the solidarity and interaction maintained between them and other organisations, and the dialogue with the members of each.

Here, I invite Louis to tell us about his perceptions regarding this presentation about social movements of resistance in Mexico.

LOUIS DI PAOLO: In my reflection on your paper I will focus on the importance of the constitutional recognition of Afro-descendants in Oaxaca in 2013, as well as the creation of new possibilities for political action among Afro-descendant groups through a legal identity, centring on the Afro-Mexican Council, created in 2014. Professor Heriberto Ruiz Ponce presented this research, jointly conducted with Selma Jazmín Vásquez Bracamontes, on Afro-descendant political identities in the state of Oaxaca. Their analysis was framed with a decolonial perspective, based on Aníbal Quijano's discussion on the "coloniality of power", which states that the classification 
of ethnicities and races in the Global South is a fundamental instrument sustaining the domination of global capitalism. This discussion is closely linked to the historical ideas in Western philosophy in which Africa belongs to an imaginary of underdevelopment, legitimising this system of codification.

Ruiz Ponce and Vásquez Bracamontes demonstrate that there has been an increase in the number of individuals who self-identify as Afro-descendants in the State. They examine the relationships that exist between this increase in Afro-descendant selfidentification and the processes of political discussion. The constitutional reform, which was catalysed by Afro-descendant activist groups, has generated new political spaces to broaden the Afro-Mexican struggle in the state of Oaxaca, through the creation of this legal identity.

This research into this legal identity opens new discussions about the crossroads between social change and the negotiation of racial and ethnic identities within governmental structures. It has been a subject little studied in this region. Although these racialised subjectivities comply with liberal state ideals about identity, their permanent invisibility in the political discourse of Oaxaca before the reform prohibited such a legal instrument for these marginalised groups to claim their rights. Ruiz Ponce and Vásquez Bracamontes carefully consider the complexities of claiming rights in the political sphere by stabilising fluid subjectivities within legal and political contexts. The authors found that the constitutional reform has created new dialogues between Afro-descendant groups to establish further agendas and collective objectives.

This topic has connections with my research, as it is important to critically analyse inclusive political agendas that utilise legal and/or political identities within liberal government structures. Next, I present my paper on LGBTQ tourism in Uruguay.

\section{Decolonising 'Gay Friendly' in Uruguay}

LOUIS DI PAOLO: In 2016 Uruguay was awarded the title of being the most 'gayfriendly' country in Latin America by the international gay tourism guide, Spartacus. 
This was due to the new rights agenda established in the country, with the most important achievements being marriage equality and the passing of child adoption laws for same-sex couples. This international (albeit frivolous) classification of social progress has been used by the Ministry of Tourism to promote Uruguay as 'gayfriendly' and an attractive destination for the affluent gay traveller, commodifying the achievements of civil society activism.

This appropriation of struggles by the State for market purposes demonstrates the culmination of the dangers of what María Galindo (2015) calls the 'NGOigisation' of social movements of groups historically discriminated against in Latin America in their struggle for equality within the neoliberal system, taking place through egalitarian and consumerist discourses. María Galindo (2015) argues that this is a new form of clientelism, where the financing of groups reproduces the same commercial interests as in the state. In tourism studies and some sectors of international relations there is a belief that LGBT tourism has a positive impact on the promotion of social rights of these groups worldwide, which is also supported by the United Nations tourism organisation (Vorobjovas-Pinta \& Hardy 2016). This is reflected in the foreign policy of the United States, through USAID. In 2016, this agency donated one million dollars to the Dominican Republic to promote LGBT rights, for the development of LGBT tourism in the country (Taveres, 2016), which is also a foreign relations policy within the Southern Cone through activities promoted by embassies of the Global North. This shows the importance of analysing these clientelist and colonial processes closely because, as Puar (2002) argues in their critique of transnational LGBT tourism in the Caribbean, this economic access for some invisibilizes and further marginalises more dissenting gender variant subjectivities and their more pressing needs.

When critically analysing the strategies of the promotion of LGBT tourism in Uruguay, in this paper, I wanted to emphasise the importance of a self-criticalanalysis as a way to decolonise the academia of the Global North. Through this, my reasons for studying LGBT tourism in Uruguay were self-reflexively revealed to me as an extension of homonormative discourses and practices (Duggan, 2003), due to 
my privileged hope in the discourses of liberal equality espoused by rainbow capitalism. It is necessary to be critical of the spaces and practices that we intend to research, but if one does not question and criticise one's own positioning within colonial structures as researcher and subject, we would merely reproduce colonial researcher relationships with the field, replicating neoliberal logics within Queer theory of the North.

I now invite Katucha Bento to reflect upon my presentation, which relates to her presentation about the importance of an intersectional view between oppression and identity processes.

KATUCHA BENTO: It has been a pleasure to organise this symposium and have you present, Louis, in our dialogue. I see your contribution as necessary to promote reflexivity in the research process (for reflexivity as an epistemic concept see: Tate, 2005; Gill, 1998). The key point that caught my attention is that you and I both self-identify with the topic of our research. It certainly doesn't talk about the only form of our identity, but it is crucial for the role that we have/complete in the world. Because of this, I start with a reflection about how the Global North uses a type of "intersectional" to makes calls for LGBTQ+ tourism in Uruguay.

It is clear that this is the classic colonisation of knowledge by hegemonic groups (white, Eurocentric, upper-middle class) that make use of the terminology of resistance, in this case, black feminism. The notion of intersectionality proceeds to have an exchange value, commercialised through an imaginary alternative, which, at the same time as it celebrates alternative sexualities, renders oppressed groups invisible from their partaking in such activities. This is a problematic contradiction that requires deeper reflections within these collectives about the promotion of selfcritique and inclusive spaces.

Shirley Tate (2015) takes into account a Foucauldian, decolonial and black feminist approach in her analysis of the (in)visible spaces of black British women's bodies. This is a sophisticated reflection, which seems simple but in which it is difficult to strike a balance, on the danger of the normalisation, disciplining and observation of 
the body. Shirley speaks of how our ability to resist power withdraws when we become agents of our own normalisation, creating categories of classification, discursive norms and measures of difference (Tate, 2015, p. 4). Louis and Shirley inspire me to call attention to reflexivity in our roles as researchers, seeking to understand our positions of power before our participants, and as activists that make us part of the groups of resistance. Turning ourselves into agents of our own normalisation can permit new modes of exclusion, which is what Louis lays out in his presentation. By not being in constant change and negotiation, with respect to the discursive norms of resistance, the "gay friendly" that Louis presents becomes an exclusive mode of differentiation and marginalisation marked by capitalist logics.

The oppressive process that we feel, (don't always) survive, and (don't always) recover from demands a constant questioning of the consequences of the alliances and breakages we make with capitalism. Such negotiations are affected by colonialities of power that keeps us, the queer population, among marginalised groups, independent of the economic ascension that allows us to exclude "Other" subjects from our collectives.

Louis's presentation has awoken greater interest in me to accompany his investigation, as I believe that reading about queer spaces, subjectivities and identities will provide us with much fruit for decolonial thinking.

\section{Final Considerations}

The dialogue presented in this article discusses the failure of the State in recognising the identities of marginalised groups with the oppressions suffered by such groups. In the different papers presented at our panel, it was asserted that the State is, in fact, an active force in oppressing non-white bodies and lives on the basis of what Charles Mills (1997) called the "Racial Contract," which has historically allowed formal and informal practices of domination on non-white bodies and lives to benefit whiteWo/Man-Eurocentric/Western hegemonic power. We understand that the practices 
of racism, homophobia, sexism, ableism and de-territorialization presented in this article, despite taking place in private settings, are authorised practices by State institutions created to serve the purpose of coloniality of power (Quijano, 2000).

As Katucha Bento's presentation showed, the lack of recognition of Ceci as a victim of domestic violence already implied a set of multiple oppressions of patriarchy. In other words, this lack of recognition is a form of naturalising moral, physical and psychological harassment against women in public and private spheres. At the institutional level, Ceci's case is also an example of how the State trivialises structural violence against women since it does not promote policies that address this violence, nor which protect its victims, and is equally uninterested in designing educational projects for aggressors.

In Andrea Sempertegui's presentation, the State appears once again as the leading promoter of oppressive practices against marginalised groups, failing to recognise the negative impacts produced by the extractive occupation of land in the Amazon. Extractive occupation also implies the oppression of people and nature, the imprisonment of activists, the production of gender inequalities, and the death of political activists. Nevertheless, racialised groups - as non-whites - in Latin America, have historically brought attention to these implications, as the case of the group of indigenous women who initiated the "March for Life" demonstrates. Their struggle against the extractive policies promoted by the government is thus not only an act of resistance but of their capability of "re-existing" extractivism despite territorial colonisation.

The coloniality of power represented by the State is also present in the lack of recognition of racialised identity groups. Heriberto Ruiz Ponce pointed out in his presentation the importance of recognising black peoples as subjects in the Mexican political context as a necessary step to advance social equality programs. Afromexican identities thus matter for just social organisation, and they need to be validated and understood at the national level not as conflictive identities but as possibilities for producing positive transformations. This is the case of the Afromexican Council's 
proposal that has worked for the recognition of rights of Afromexican peoples, an invisible group for Mexican society.

Louis Di Paolo also offered us his critical vision of State clientelistic practices that perpetuate colonial processes within the LGBTQ community, through commercialised identity recognition. The State does this by approving laws that, while meeting the demands of some, reproduce hegemonic, white and normative patterns that render as invisible the identities and needs of the most vulnerable subjects within the LGBTQ community. The effect of this process is that LGBTQ discourses and practices become homonormative and that State recognition of LGBTQ identities is commodified through tourism development discourses and practices, serving the economic interests of the state, creating an illusion of inclusion, at the expense of dissident and vulnerable subjectivities.

All the presentations showed that resisting the coloniality of power is necessarily an intersectional practice. In fact, resisting as politicised subjects is a revolutionary practice of reclaiming our own space of existence in a continent that suffers the consequences of colonisation, a product of the enslavement of our ancestors, the expropriation of indigenous lands and the dismissal of our ways of producing knowledge. This knowledge has been presented in this dialogue as situated forms of knowledge coming from our racialised, gendered, sexual and national realities. To recognise and make visible the situatedness of our experience is an important step to enable possibilities for decolonising the practices that exclude us.

Furthermore, having done this collective work as a way of connecting our different ways of knowing, it is already an emancipatory practice that has the potential to break with colonial shackles and to promote diverse forms of re-existence. In other words, this work in eight hands is an invitation to create collaborative practices and to decolonise beyond the oppressive state. This is thus a proposal for constructive dialogues and practices that shed light on our potential as subjects of transformation. To recognise marginalised spaces and subjects is also a necessary and collective academic task that can open spaces for serious dialogue amongst groups, taking into account our privileged places of enunciation. 


\section{References}

Acosta, A. (2012). "Extractivismo y Neoextractivismo: Dos Caras de la Misma Maldición". Available at: http://www.ecoportal.net (25.07.2018).

Ahmed, S. (2004a). The cultural politics of emotion. Edinburgh: Edinburgh University Press.

Ahmed, S. (2004b). Affective Economies. Social Text 1 June; 22: 2 (79): 117-139.

Bhattacharyya, G. (2018). Rethinking Racial Capitalism. Questions of Reproduction and Survival. London: Rowman \& Littlefield.

Arif, I. and Wangari-Jones, P. (2018) 'Home Office's "Hostile Environment": Segregates migrants and encourages racial profiling', Politics Means Politics, 22 March. Available at: https://vip.politicsmeanspolitics.com/2018/03/22/home-officeshostile-environment-segregates-migrants-and-encourages-racial-profiling/.

Carby, H. V. (1982). "White Woman Listen!: Black Feminism and the Boundaries of Sisterhood", in: The Empire Strikes Back: Race and Racism in Seventies Britain, 212-235. London: Hutchinson.

Cielo, Cristina; Coba, Lisset; Vallejo Ivette (2016) "Women, Nature, and Development in Sites of Ecuador's Petroleum Circuit”. Economic Anthropology, Vol. 3, Issue 1,119-132.

Cielo, Cristina et al. (2016) “Ciudades del Milenio: ¿¿Inclusión o Exclusión en una Nueva Amazonía?" En: Burchardt, Hans-Jürgen et al. (eds.): Nada Dura para Siempre: Neo-extractivismo tras el Boom de las Materias Primas. Quito: Ediciones AbyaYala, 281-316.

Collins, P. H. (1990) Black Feminist Thought: Knowledge, Consciousness, and the Politics of Empowerment. 2nd ed. New York; London: Routledge. 
Dialogues of Indigenous Afro-Latinxs (re)existence | 54

Crenshaw, K. et al. (1996) Critical Race Theory: The Key Writings That Formed the Movement, Columbia Law Review. Edited by K. Crenshaw et al. Available at: http://www.jstor.org/stable/1123408.

Galindo, M. 2015. La revolución feminista se llama Despatriarcalización. (en) Feminista Siempre: Descolonización y Despatriarcalización de y desde los feminismos de Abya Yala. pg. 27-50. ACSUR-Las Segovias.

Gill, R. 1998. 'Dialogues and differences: writing, reflexivity and the crisis of representation', in Standpoints and Differences Essays in the Practice of Feminist Psychology, eds K. Henwood, C. Griffin \& A. Phoenix, Sage, London, pp. 18-44.

Gonzalez, L. 1988. 'Por um Feminismo Afrolatinoamericano', Revista Isis, (July).

Gonzalez, L. and Hasenbalg, C. 1982. Lugar de negro, Coleção 2 Pontos. Available at: http://www.projetomemoria.art.br/leliaGonzalez/obras-em-pretugues/livrospublicados.jsp.

Gudynas, E. 2010. "The New Extractivism of the 21st Century. Ten Urgent Theses about Extractivism in Relation to Current South American Progressivism”.Americas Program Report, Washington, DC: Center for International Policy (Enero 2010).

Gutiérrez Rodríguez, E. 2010. Migration, domestic work and affect: a decolonial approach on value and the feminization of labor. London: Routledge.

Hall, S. 1996. Introduction: Who Needs Identity?, Questions of Cultural Identity. Edited by S. Hall and P. du Gay. London: SAGE Publications. doi: 10.4135/9781446221907.

Lorde, A. 1984. Sister Outsider. California: The Crossing Press.

Mills, C. W. 1997. The Racial Contract. Cornell University Press. Available at: http://www.jstor.org/stable/10.7591/j.ctt5hh1wj.

Mujeres Amazónicas del Centro Sur, Movilización Por la Vida. 2013. "Declaratoria del Kawsak Sacha". GONOAE: Gobierno de las Naciones de la Amazonía Ecuatoriana (CONFENAIE), Puyo-Pastaza (Octuber 2013). 
Muñoz, J. E. 2006. "Feeling Brown, Feeling Down: Latina Affect, the Performativity of Race, and the Depressive Position" In: Signs: Journal of Women in Culture and Society 31 (3): 675-688.

Muñoz, J. E. 1999. Disidentifications: Queers of color and the performance of politics. Minneapolis: University of Minnesota Press.

Phoenix, A. and Pattynama, P. 2006. 'Intersectionality', European Journal of Women's Studies, 13(3), pp. 187-192.

Puar, J. 2002. A transnational feminist critique of queer tourism. Antipode, 34(5), 935-946.

Quijano, A. 2000. 'Coloniality of Power and Eurocentrism in Latin America', International Sociology, 15(2), pp. 215-232. doi: 10.1177/0268580900015002005.

Robinson, C. 1983. Black Marxism: The Making of the Black Radical Tradition. London: Zed Books.

Svampa, M. 2011. "Modelo de desarrollo y cuestión ambiental en América Latina: categorías y escenarios en disputa”. En: Wanderley, Fernanda (ed.): El Desarrollo en Cuestión: Reflexiones desde América Latina. La Paz: CIDES / UMSA, 411-444.

Tate, S. A. 2005. Black skins, Black masks: hybridity, dialogism, performativity. Aldershot, Hants, England, Burlington, VT: Ashgate.

Tate, S. A. 2015. Black women's bodies and the nation: race, gender and culture. Basingstoke: Palgrave Macmillan.

Taveres, E. 2016. Usaid financia actividades LGBT del país con un millón de dólares: Entre ellas está la promoción de candidatos con esas preferencias y la cámara de comercio gay. El Día, Santo Domingo, 3o de Marzo, 2016.

Vorobjovas-Pinta, O., \& Hardy, A. 2016. The evolution of gay travel research. International Journal of Tourism Research, 18(4), 409-4 